\title{
Teacher Competencies for Dyslexia Students
}

\author{
Juhri Abdul Muin*, Riyanto, Satriyo Budi Wibowo \\ Universitas Muhammadiyah Metro, Lampung, Indonesia
}

Received December 8, 2019; Revised January 13, 2020; Accepted February 7, 2020

Copyright $(2020$ by authors, all rights reserved. Authors agree that this article remains permanently open access under the terms of the Creative Commons Attribution License 4.0 International License

\begin{abstract}
Purpose: This study aims to identify the competencies that teachers have in dealing with dyslexic students. Method: The type of research used is quantitative which uses a research design survey that is strengthened by the results of interviews to support the results of quantitative data. Where the total number of samples from this study were 91 teachers taken based on the total sampling technique. Data were then analyzed with the help of the SPSS 21 application to look for descriptive statistics in the form of mean, median, min, max, and category. Findings: From the results of the analysis conducted, it is found that there is a teacher's ability to handle dyslexic students in the good category, which is indicated by a good category of $64.8 \%$ (59 of 91) students. Implications and Recommendations: For this reason, it is recommended that teachers need to have good competence in order to help dyslexic students. Students need to be given the opportunity to develop direct experiences and thoughts in learning activities.
\end{abstract}

Keywords Competencies, Dyslexia, Teachers

\section{Introduction}

Dyslexia is a developmental disorder of reading caused by cognitive processing dysfunction in the brain [1]. The main symptom of dyslexia usually appears when students enter the beginning of primary school. Because at the elementary school age, new students begin to be taught early reading. When the cause of the learning to read failure is not detected properly by the teacher, it will cause many problems for student academic development. The Mathew Effect's Law states that the more skilled students in reading, they will have a better chance of developing linguistic, understanding and cognitive skills [2]. On the contrary, as the students' reading skills become worse, opportunities for developing linguistic, understanding and cognitive skills are reduced. Reading ability is very important for information processing, difficulty in mastering reading skills will make students more difficult in information processing. These difficulties cause children who have reading difficulty in primary school, will experience academic difficulties at the next level [3]. The role of primary school teachers in recognizing and managing the dyslexia symptoms that appear in students is very important. The failure of teachers in identifying that the reading problem difficulties in dyslexia as a cause of failure of one part of the brain, can interfere with the proper handling of reading difficulties.

Since 2003, Metro has been designated a city of Inclusion and has entered into an memorandum of understanding (MoU) with UNESCO to organize inclusive education in Metro [4]. The launching of Metro as the City of Inclusion, followed by the appointment of several schools to become inclusive schools. Determination of some primary schools as inclusive schools, causing schools to have an open opportunity to get students who have difficulty learning to read or dyslexia. Based on the International Dyslexia Association (IDEA) estimate, the number of dyslexic students is $10 \%$ of normal students. Based on these data, not only in inclusive schools, the opportunity for dyslexic students to be in elementary school is also very open. Teachers failure in dealing with dyslexic students can be attributed to the low competence of primary school teachers, especially in the skills of dealing with dyslexic students [5]; [6]; [7]. Primary school teachers, from elementary school teacher education graduates. In the undergraduate curriculum of primary school teacher education, learning to handle dyslexic students is not given. Therefore, the Metro city government through the Education Office held several pieces of training for teachers in charge of inclusive primary schools, in order to handle students with special needs well [8]; [9]. Additional training is expected to improve the competence of primary school teachers in dealing with students with special needs, including dyslexia students.

Based on some research results, the implementation of inclusive schools in Metro has not been maximized. [10] mentions that inclusive schools are not yet ready for dealing with students with special needs. There is no individual curriculum for students with disabilities in inclusive schools. Some of these studies, indicating that students with special needs are not handled properly [11]; [12]; [13]. If in general the students with special needs are 
not handled properly, then dyslexic students are assumed will not be handled properly. Failure to handle dyslexia students well adversely affects the academic life of dyslexic students. In fact, dyslexic students have the potential to develop into extraordinary individuals. Alber Einstein and Thomas Alva Edison are some examples of great inventors who in childhood experienced dyslexia [14]; [15]. Dyslexic students who are not handled properly in elementary school will limited the chances that the student develops into a great individual in adult life.

As explained earlier, the role of primary school teachers is crucial in addressing dyslexic students. Dyslexia symptoms usually appear at the early age of school, when the child begins learning to read. Teachers who have good competence in dealing with dyslexic students, can ensure the success of reading learning dyslexic students [16]; [17].

By having good competence, the teacher is able to educate dyslexic students well. Therefore the researcher wants to see the competency ability possessed by the teacher in educating dyslexic students, in order to be able to assist the government in applying about inclusive education run by the city government of the metro.

\section{Materials and Methods}

\subsection{Research Design}

The research design used by researchers is quantitative research that uses the research design is survey research. Survey research is a procedure in quantitative research where researchers administer surveys to a sample or to the entire population used to describe population attitudes, opinions, behaviors, or special characteristics [18]; [19]. The design of this study was applied because it was in accordance with the objectives of the study, where the aim was to find out the problem solving ability of Junior High School Students to the Subjects of Mathematics.

\subsection{Research Subject}

The research sample was obtained from 91 teachers in the Elementary School in the Metro district used a total sampling technique, with 65 female teachers and 26 male teachers. With details of Elementary School 1 Metro Pusat, Elementary School 1 Metro Timur, Elementary School 2 Metro Timur, Elementary School 2 Metro Barat, Elementary School 2 Metro Pusat, Elementary School 3 Metro Pusat, Elementary School 8 Metro Pusat, Elementary School 2 Metro Utara, Elementary School 1 Metro Utara and Elementary School 6 Metro South. The technique of taking total sampling involves or takes all samples in the population [20].

\subsection{Research Instrument}

In this study, the study used questionnaire and interviews instruments. The questionnaire has 20 valid statements with a reliability value of 0.73 using a Likert 4 scale and using structured interviews aimed at strengthening quantitative data. The data used by the SPSS program to look for descriptive. Descriptive statistics are presented in a summary frequency, for example, mode, mean, median, minimum, maximum and standard deviation [21].

The categories competencies of teachers ability regarding dyslexia students, very good, good, not good, and very not good, like table 1 in below:

Table 1. Categories of Teacher's Competences

\begin{tabular}{cc}
\hline Category & Interval \\
\cline { 2 - 2 } & Teacher's ability \\
\hline Very Not Good & $20.0-35.0$ \\
Not Good & $35.1-50.0$ \\
Good & $50.1-65.0$ \\
Very Good & $65.1-80.0$ \\
\hline
\end{tabular}

\subsection{Analysis Data}

All data were obtained from teacher ability questionnaire collected and calculated and assisted with the SPSS 21 application. In this study, quantitative data were analyzed using Mean, Median, Min, Max, and Percentage. Descriptive statistics are given to calculate the frequency, percentage, mean, median, min, and max of sample [19] And followed by interviews that are used to strengthen the results of quantitative data. Followed by interviews intended to strengthen the results of quantitative data. The steps in the interview can be seen as follows: (1) the ideas, themes, pieces of data and words. (2) pay attention to patterns and themes. (3) try to make good data, using intuition to reach conclusion. (4) is a group set items into categories, types, behavior, and classification? (5) makes a metaphor that uses figurative language and connotative rather than literal and denotative language, animates data, reducing data, making patterns, aligning data, linking data with theory. (6) separate variables to decipher, differentiate and 'unpack' ideas, ie move from drive to integration and obfuscate data. (7) surrendered specifically into the general, large number of variables under a small number of (frequently) unobserved hypothetical variables. (8) identifies and records relationships between variables. (9) finds an intervening variable: looks for another variable that seems to be a 'block' calculation for what is expected to be a strong relationship between variables. (10) the logical chain of evidence building: noting causality and making conclusions. (11) Creating conceptual/theoretical coherence: moving from a method to construct stories to explain phenomena [21].

\section{Results and Discussion}

The results of the teacher's questionnaire in dealing with dyslexic students are given and have been obtained and processed the results using the SPSS 21 application which we can see in the table below: 
Table 2. Results of the teacher's competence to cope with dyslexic students

\begin{tabular}{|c|c|c|c|c|c|c|c|c|}
\hline \multicolumn{5}{|c|}{ Classification } & \multirow{2}{*}{ Mean } & \multirow{2}{*}{ Min } & \multirow{2}{*}{ Max } & \multirow{2}{*}{$\%$} \\
\hline Range & M & $\mathrm{F}$ & Responses & Total & & & & \\
\hline $20.0-35.0$ & 0 & 0 & Not very good & 0 & \multirow{4}{*}{57.5} & \multirow{4}{*}{37.0} & \multirow{4}{*}{79.0} & 0.0 \\
\hline $35.1-50.0$ & 6 & 5 & Not good & 11 & & & & 12.1 \\
\hline $50.1-65.0$ & 12 & 47 & Good & 59 & & & & 64.8 \\
\hline $65.1-80.0$ & 8 & 13 & Very good & 21 & & & & 23.1 \\
\hline TOTAL & 26 & 65 & & 91 & & & & 100 \\
\hline
\end{tabular}

From table 2, which came from 91 respondents from high school teachers in the good category, and after being processed and obtained the results using the SPSS 21 application program, it was found that the ability of teachers to overcome dyslexic students had a good category of $64.8 \%$ for 59 teachers from 91 total teachers, not good at $12.1 \%$ for a total of 11 teachers out of 91 total teachers, and very good $23.1 \%$ for 21 teachers out of 91 total teachers. Of the 91 teachers having a Mean value of 57.5, Maximum Value of 79.0, and Minimum Value of 37.0.

The results of the questionnaire analysis of the ability of teachers in table 2, have a good ability of $64.8 \%$ (59 of 91) students. This ability is shown by the teacher being able to handle students well. In order to handle dyslexic students well, teachers need to first understand dyslexic students.

This is reinforced by the results of interviews that have been conducted, found that teachers who have good competence in educating students, are able to understand and comprehend dyslexic students. The teacher said that by understanding and understanding the dyslexic students he taught, it would be easier for him to teach or apply the methods or models of learning that had been taught by the teacher through training that had been followed by him.

Because, the metro city government often conducts training activities or workshops on inclusive education to improve the competence of teachers involved in it. From the results of training or workshops that have been carried out the teachers are expected to become pilots or spearheads in inclusive education that is initiated by the city of metro. Therefore, this research is in line with the results of the study found that teachers have good competence, supported by the results of the questionnaire that has been given, and strengthened by the results of interviews conducted.

The main symptom of dyslexia is low reading skills. Low reading skills cause dyslexic children to have difficulty in academic tasks, resulting in low academic achievement. Ignorance teacher's understanding of dyslexia, making dyslexic children who have low academic achievement sometimes labeled naughty or lazy [22]. Whereas low learning achievement caused by low reading skill in a dyslexic student not caused by laziness, but because there is dysfunction of neurology system in the brain.

Diagnostic and Statistical Manual of Mental Disorders V-edition (DSM V) enters Dyslexia into a specific subgroup of learning dificulties. DSM V specified learning disorders are diagnosed as deficits in the acceptance and processing information effectively and accurately in individuals [23]. The special characteristics of dyslexic persons mentioned in DSM 5 are, difficulty learning and using academic skills with symptoms of learning difficulties that persist for more than 6 months, especially in dyslexia, encountered disability in reading accuracy, fluency in reading, and comprehension of reading [23]. Furthermore, failure to learn to read in dyslexic children due to dyslexia has a problem in the process of recognizing letters fluently and accurately, bad in coding letters, and have poor spelling ability [23].

Many professional definitions of dyslexia highlight the same important feature, that, a dyslexic child has an "unexpected" disability in the reading domain [24]. Specifically, the "unexpected" disability affects the reading accuracy, reading fluency, and reading comprehension [23]. The reading disability is due to the disability contained in the cognitive processing domain. Cognitive processes are responsible for learning and information processing [25]. It refers to how information is processed, which affects memory, processing speed, and the ability to store and transfer information, to develop prior learning and develop automation [26]. Difficulties in processing information are the most obvious indicators of dyslexia. Students with dyslexia can solve problems and can unravel reasoning, but often they have difficulty in processing information and accessing information to help them solve problems [27]. Difficulties in receiving and processing information on individuals will have an impact on learning difficulties of fundamental things in school, especially reading.

The phonological deficit theory explains the causes of dyslexia. Through the use of fMRI, researchers at the Yale University Center for Learning and Attention found that people with normal phonological awareness can quickly process written words [28]. When normal children are asked to imagine "block" without sound "buh", they can quickly call the word "lock." Results of FMRI 
photographs in non-dyslexic children show that phonological processing makes the inferior frontal gyrus (Broca area of the Brain) burning [29].

Neurological research findings support the phonological model theory of dyslexia, suggesting deficit in the brain found that blocking phonological processing in all dyslexic patients. Further neurological support for phonological models has come from a recent study, which sees dyslexia from a cross-cultural perspective. The results show that, regardless of language differences, people with dyslexia exhibit lower activity in the nerve centers of language processing in the brain [30]; [31].

The phonological theory models in explaining dyslexia argues that dyslexic have impaired reading ability because they have deficits in phonological processing. According to this model, dyslexic have difficulty with written language because they have an impaired ability to deconstruct written words into phonemes, thus blocking the process of identifying words. This phonological deficit prevents dyslexic to achieve deeper linguistic processing, which prevents the reader from understanding the meaning of the text [32]; [33]. Therefore, in dyslexic patients, intact memory and understanding processes are not activated, because dyslexic patients can only activate it after identifying the word through phonological processing. This phonological model of dyslexia explains why dyslexic people have difficulty reading, but still have the intellectual ability to process more complex thoughts and ideas [34]; [35].

Some of these studies are able to prove that one of the core deficits in dyslexic is on the phonological processing. When a dyslexic person has a deficit in phonological processing, then interventions that can be given can also be focused on dealing with deficits in phonological processing. A study by Slaughter showed that phonological awareness training interventions improved reading ability, while other language training programs did not [28].

\section{Conclusions}

From the results of the analysis that has been done, it was found that there is a teacher's ability to handle dyslexic students in the good category, which is indicated by a good category of $64.8 \%$ (59 of 91) teachers. This is reinforced by the results of interviews conducted, that teachers are able to recognize and educate dyslexic students well because teachers have good competence because they have conducted training/workshop that has been carried out by the government, in order to support programs that have been carried out by the city government of Metro with UNESCO in dealing with children with special needs by implementing inclusive education. For this reason, it is recommended that teachers need to have good competence in order to help dyslexic students.

\section{Acknowledgments}

Thank you to all the principals of the Metro Lampung City Elementary School, who have allowed me to do this research, and all the teachers who have agreed to be a sample in this study.

\section{REFERENCES}

[1] Reid, G. (2009). Dyslexia: a practitioner's handbook (4th ed). Chichester; Malden, Mass: Wiley-Blackwell

[2] Stanovich, K. E. (1991). The construct validity of discrepancy definitions of reading disability. In $\mathrm{G}$.

[3] Snow, Burns, M.S. \& Griffin, P. (eds) (1998), Preventing reading difficulties in young children, National Research Council Washington, DC: NationalAcademic Press

[4] United Nations Educational, Scientific and Cultural Organization (UNESCO). (2001). Understanding and Responding to Children's Needs in Inclusive Classrooms. Diunduh dari

http://www.unesco.org/education/educprog/sne

[5] Astalini., Kurniawan, D. A., Sulistiyo, U., Perdana, R., Susbiyanto, S. (2019). E-Assessment Motivation in Physics Subjects for Senior High School. International Journal of Online and Biomedical Engineering (iJOE). 15(9), 4-15.

[6] Astalini., Darmaji., Kurniawan, W., Khairul, A., \& Kurniawan, D. A. (2019) Effectivenes of Using E-module and E-Assessment. International Journal of Interactive Mobile (IJIM), 13(9), 21-39.

[7] Darmaji., Kurniawan, D. A., Astalini., Lumbantoruan, A., \& Samosir, S. C. (2019). Mobile Learning In Higher Education For The Industrial Evolutioin 4.0: Perception and Response of Physics Practicum. International Journal of Interactive Mobile (IJIM), 13(9), 4-20

[8] Wibowo, S, B., \& Anjar, T., (2015). Studi Kasus Pola Relasi Sosial Anak Berkebutuhan Khusus (ABK) Tuna Daksa yang Berada di SD umum (inklusi) di Kota Metro. Jurnal Sosio-Humaniora. Vol 6, No 1.

[9] Asrial., Syahrial., Kurniawan, D. A., Subandiyo, M., Amalina, N. (2019). Exploring obstacles in language learning among prospective primary school teacher. International Journal of Evaluation and Research in Education (IJERE), 8(2), 249-254.

[10] Asrial, Syahrial, Kurniawan, D. A, Chan, F., Nugroho, P., Pratama, R. A., Septiasari, R. (2019). Identification: The Effect Of Mathematical Competence On Pedagogic Competency Of Prospective Teacher. Humanities \& Social Science Reviews (HSSR). 7(4), 85-92

[11] Darmaji, D., Kurniawan, D. A., \& Irdianti. (2019). Physics education students' science process skills. International Journal of Evaluation and Research in Education (IJERE), 8(2), 293-298

[12] Astalini, Kurniawan, D. A., Darmaji, Sholihah, L. R., Perdana, R. (2019).Characteristics Of Students' Attitude 
To Physics In Muaro Jambi High School. Humanities \& Social Science Reviews (HSSR), 7(2), 91-99

[13] Maison, Darmaji, Astalini, Dwi Agus Kurniawan, Peni Sefiah Indrawati. (2019). Science Process Skills And Motivation. Humanities \& Social Science Reviews (HSSR), 7(5), 48-56.

[14] Fawcett, A., \& Nicolson, R. (2017). Dyslexia in children. Routledge.

[15] Gang, M., \& Siegel, L. S. (2002). Sound-symbol learning in children with dyslexia. Journal of Learning Disabilities, $35(2), 137-157$

[16] Asrial., Syahrial., Kurniawan, D. A., Chan, F., Septianingsih, R., Perdana, R. (2019). Multimedia Innovation 4.0 in Education: E-Modul Ethnoconstrucivism. Universal Journal of Educational Research. 7(10), 2098-2107.

[17] Maison., Astalini., Kurniawan, D. A., Perdana, R. Anggraini, L. (2019). The Phenomenon of Physicology Senior High School Education: Relationship of Students' Attitudes towards Physics, Learning Style, Motivation. Universal Journal of Educational Research. 7(10), 2199-2207.

[18] Cramer, D. (2003). Advanced quantitative data analysis McGraw-Hill Education (UK).

[19] Creswell, John W. 2012. Educational Research: Planning, Conducting, And Evaluating Quantitative And Qualitative Research. New York: Pearson

[20] Kerlinger, F. N. (2014). Foundations of behavioral research. Yogyakarta: Gadjah Mada University Press.

[21] Cohen, L., Manion, L., \& Morrison, K. (2005). Research Methods In Education: Routledge.

[22] Ramus, F. (2003). Developmental dyslexia: specific phonological deficit or general sensorimotor dysfunction?. Current opinion in neurobiology, 13(2), 212-218

[23] American Psychiatric Association, \& American Psychiatric Association (Eds.). (2013). Diagnostic and statistical manual of mental disorders: DSM-5 (5th ed). Washington, D.C: American Psychiatric Association.

[24] Reiter, A., Tucha, O., \& Lange, K. W. (2005). Executive functions in children with dyslexia. Dyslexia, 11(2), $116-131$

[25] Fawcett, A. J., \& Nicolson, R. I. (1994). Naming speed in children with dyslexia. Journal of Learning Disabilities, 27(10), 641-646.

[26] Jordan, D. R. (2002). Overcoming dyslexia in children, adolescents, and adults. PRO-ED, Inc. 8700 Shoal Creek Blvd., Austin, TX 48757-6897 (Order no. 9296, \$39).

[27] Démonet, J. F., Taylor, M. J., \& Chaix, Y. (2004). Developmental dyslexia. The Lancet, 363(9419), $1451-1460$.

[28] Slaughter, G. (2001). The phonological model of dyslexia. Retrieved Mar 18, 2016, from http://www.serendip.brynmawr.edu/bb/neuro/neuro01/web 3/slaughter.html
[29] Snowling, M. J. (2019). Dyslexia: A Very Short Introduction. Oxford University Press.

[30] Paulesu, E., Demonet, J F., Fazio F, McCrory, E, Chanoine, V., Brunswick, N., Cappa, S F., Cossu, G., Habib, M., Frith, C D., \& Frith, U. (2009). Dyslexia; Cultural Diversity and Biological Unity.Science. Vol 291, 2165. DOI: $10.1126 /$ science. 1057179

[31] Peterson, R. L., \& Pennington, B. F. (2012) Developmental dyslexia. The Lancet, 379(9830), 1997-2007.

[32] Shaywitz, S. E., \& Shaywitz, B. A. (2005). Dyslexia (specific reading disability). Biological psychiatry, 57(11), 1301-1309.

[33] Tunmer, W., \& Greaney, K. (2010). Defining dyslexia. Journal of learning Disabilities, 43(3), 229-243.

[34] Pennington, B. F., \& Olson, R. K. (2005). Genetics of dyslexia. The science of reading: A handbook, 453-472.

[35] Patterson, K., Marshall, J. C., \& Coltheart, M. (2017). Surface dyslexia: Neuropsychological and cognitive studies of phonological reading. Routledge. 